\title{
LXIV. On subterranean temperature, as observed at a depth of five hundred yards below the level of the sea, in latitude $54^{\circ} 55^{\prime}$ North, November 15 , 1834
}

John Phillips F.R.S. F.G.S.

To cite this article: John Phillips F.R.S. F.G.S. (1834) LXIV. On subterranean temperature, as observed at a depth of five hundred yards below the level of the sea, in latitude $54^{\circ}$ 55' North, November 15, 1834, Philosophical Magazine Series 3, 5:30, 446-451, DOI: 10.1080/14786443408648504

To link to this article: http://dx.doi.org/10.1080/14786443408648504

曲 Published online: 01 Jun 2009.

Submit your article to this journal ¿

Џll Article views: 4

Q View related articles ¿ 
These experiments have not as yet been performed with minute attention as to the proportions of the acting bodies, although such investigation is contemplated; but it is concluded, that the chlorine of the chloride of sodium obtains hydrogen from the water of the oxalic acid to evolve muriatic acid gas, and that the sodium, obtaining its oxygen from the oxygen of the water, forms soda, which combines with the oxalic acid, forming oxalate of soda, decomposable at a red heat into carbonate of soda.

The chloride of calcium also undergoes decomposition when heated with oxalic acid, evolving muriatic acid gas, and forming oxalate of lime, which upon the further continuance of the heat leaves lime.

These researches will be extended to the other chlorides, with the view of getting new results; in the mean time it is hoped that the facts now stated possess some claim to originality.

LXIV. On Subterranean Temperature, as observed at a Depth of Five Hundred Yards below the Level of the Sea, in Latitude 54. $55^{\prime}$ North, November 15, 1834. By Јонм Phillips, F.R.S., F.G.S., Professor of Geology in King's College, London.*

1. THOUGH, upon a review of the facts and reasonings concerning the interior temperature of the globe, we may freely admit that below a certain depth from the surface the thermometric heat becomes continually greater as we descend, so many sources of embarrassment occur in the prosecution of experiments, that it is by no means an unreasonable scepticism to doubt, whether the law of the augmentation of heat in proportion to the depth is even approximately known. Those who, from local and practical experience, are the best enabled to judge of the corrections required for the effects of respiration, light, friction, and chemical action, on the one hand, and of the ventilating air on the other, must allow that the interference of these causes of error, though less considerable than is sometimes imagined, is of serious consequence in so delicate an inquiry.

2. Immediately after leaving Edinburgh, in October, I was at Newcastle for a wéek, and was informed by Mr. Hutton, of

* Communicated by the Author: in the Phil. Mag. first series, for 1823, vol. Ixi. p. 347, 436, and vol. Ixii. p. 38, 94, will be found a review, drawn up by Mr. Brayley, Jun., of the experiments on Subterranean Temperature wnich had then recently been made in the Mines of Cornwall and the North of England, exhibited in a tabular form. See also vol. Ixvii. p. 302, and Phil. Mag. and Annals, N.S. vol. ix. p. 94. 
the spirited attempt of Mr. Pemberton to reach the coal-seams which underlay the magnesian limestone of Durham, by a shaft at Monk-Wearmouth which had then reached the extraordinary depth of 250 fathoms. I mentioned to M. Arago, while he was in Newcastle, my great desire to examine in this pit, the question of subterranean temperature, before the ordinary processes of a deep colliery had complicated the investigation with unascertainable conditions; and was happy to find that a view which $I$ had formed, of relying very much on trials made in subterranean small feeders of water, met with his approval.

3. Professor Whitley, of Durham, had also considered the subject in another point of view, and on my return to Newcastle, I found my friend Mr. W. L. Wharton, of D'ryburn, engaged in arrangements for a course of experiments in the pit, which, at the enormous depth of 264 fathoms, had passed through a seam of coal 6 feet in thickness. Every facility being kindly offered by the proprietors of the colliery, (Messrs. Pemberton and Mr. Thompson, I descended the pit for the purpose of the experiments on Saturday the 15th of November, at 11 A.M., and remained nearly four hours underground, with the following gentlemen, viz. Mr. W. L. Wharton, Professor Whitley, Rev. Prof. Chevallier, Prof. Johnston, Mr. G. C. Atkinson, and several others.

Barometers and thermometers were taken by Mr. Wharton and myself, and each of the other gentlemen was provided with a thermometer. On a comparison of thermometers from $47^{\circ}$ to $70^{\circ}$, it was found that Mr. Whitley's (by Adie) agreed with one constructed by myself. By this standard, all the observations are recorded, proper corrections being applied to the other instruments.

4. The pit is 12 feet in diameter, partitioned in the usual

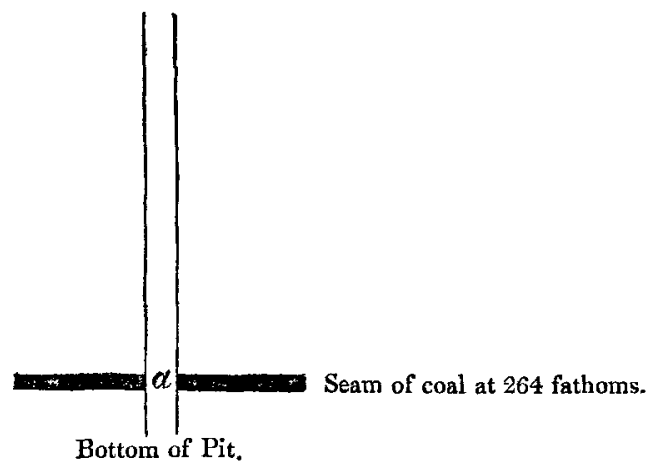

manner, and tubbed in parts to stop the entrance of water, 
which nevertheless drops, but not in great quantity, down the sides. This water falls several yards below the coal seam in which our experiments took place, into the bottom of the pit, which is to be carried considerably deeper to a lower bed of coal.

On arriving at the point $a$, we entered on the nearly level floor of the coal, and found four narrow headings driven short distances E., W., N., and S. Strong currents of air were established along the headings to sweep the fresh face of coal, from all points of which the carburetted hydrogen gas was heard to issue with a faint tinkling or humming noise, like that which might arise from the vibration of innumerable very small kettles. This gas was carried off too rapidly by the currents of air to permit any exhibition of phænomena depending on its inflammable properties, even when the Davylamp was placed in angles of the front of the coal.

By the care of Mr. Foster, the intelligent viewer, a hole was drilled in the floor of the coal seam on the dip side (east) to the depth of two feet; and when Mr.Wharton and I reached the seam, this hole was completed, and full of salt water. This station is marked $\mathbf{A}$ on the accompanying plan; it is 22 yards from the pit.

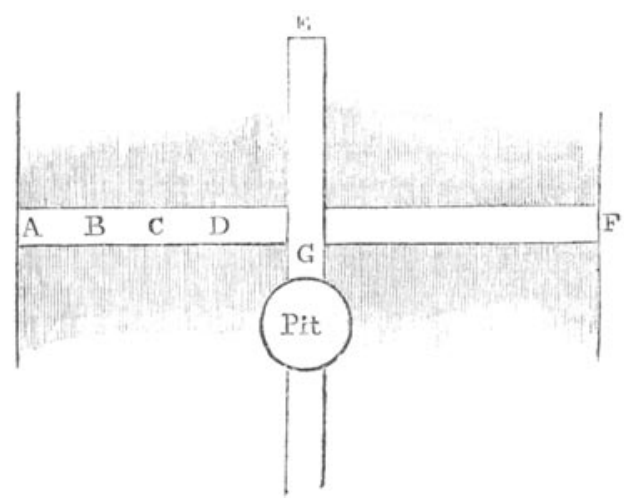

5. The first experiment was made by my going instantly to the bore-hole $A$, and trying the temperature of the water which had risen in it. By most careful observations it was found to be $70^{\circ} 1$. The air in the drift was generally $62^{\circ}$; this was the temperature of the air in the porch $G$ : it prevailed also along the drift $\mathrm{E}$, in which no one was at work, till near the forehead, when it rose to $64^{\circ}$, and close to the coal among the humming gas, which would not fire, it was $68^{\circ}$. 
Each of the thermometers belonging to the party was plunged in the bore-hole $A$, and the temperature was uniformly found about $70^{\circ}$, allowance being made for the difference of the graduation of the instruments.

6. Mr. Wharton now caused excavations to be made in the floor of the east drift to. the depth of about nine inches, and quickly inserted in each a minimum thermometer, previously heated to about $75^{\circ}-80^{\circ}$, and left them for half an hour. The temperature of the air near the surface of the floor at each point was $62^{\circ}$ to $63^{\circ}$; that of the loose small coal on the surface $64^{\circ}$ to $67^{\circ}$. It was found upon two trials that at the point $D$, nearest the pit, the temperature at this depth was $64^{\circ} \cdot 5$; at $\mathrm{C}$, further in, $66^{\circ} \cdot 4$; at $\mathrm{B}$, six yards from the forehead, $69^{\circ} \cdot 4$ and $69^{\circ} \cdot 9$. We then chose a point near $A$, within two or three yards of the forehead, and sunk the instrument deeper, so that it was quickly surrounded by the gushing salt water: when taken up it stood at $71^{\circ} .4$.

7. We next determined to try the temperature of a fresh face of cual, by picking off' a few inches in depth, and placing the thermometer in contact with the fresh face and its bulb among the particles which had fallen. The first rough trial gave $69^{\circ}$; the next a temperature continually rising till it settled at $71 \frac{1}{4}^{\circ}$.

8. In trying again the temperature of the bore-hole $A$, we observed that the thermometer fluctuated through a full degree, being highest whenever bubbles of gas rose more rapidly through the water, and lowest when these ceased for a while. It was also found that this water, notwithstanding the effect of human bodies, lights, \&c., was continually cooling by the current of air in the drift. At 2 P.M. its temperature was $69^{\circ} \cdot 7$ when air-bubbles rose in abundance, and $69^{\circ} \cdot 1$ when this was not the case. Some time later it was again registered $69^{\circ} \cdot 6$ and $69^{\circ} \cdot 3$.

Finding this to be uniformly the case, we returned to the little pit near $A$, and found by a delicate thermometer the temperature of the water when bubbles abounded to be $72^{\circ} \cdot 6$, and $71^{\circ} 6$ and $72^{\circ}$, when they ceased.

9. While these experiments were in progress, Mr. Whitley caused a hole two feet six inches in depth, to be made in the floor of the coal in the forehead of the west or rise drift $F$, and in this he poured water at $56^{\circ}$ Fahr., and then with particular precautions introduced a thermometer at 2 P.M. The men were directed to abstain fron entering this drift, till, on Monday morning, after an interval of two days, Mr. Whitley returned, and with Mr. G. Atkinson, drew out the thermometer and found it to stand at $71^{\circ} \cdot 2$. As Mr. Whitley has

Third Series. Vol. 5. No. 30. Dec. 1834. 
made arrangements for repeating this interesting experiment, under different conditions, I shall not further anticipate the account, which I hope he will soon publish, of the result of his labours.

10. The temperature of the water collected in the pit bottom was $67^{\circ}$. The barometric observations were:

\section{B. I'. Att.Th. Det. Th.}
At the top .... at
At the bottom at
11 A.M. $30 \cdot 518$
$\left.\begin{array}{cc}53^{\circ} & 49^{\circ} \\ 58 & 62 \\ 58 & 49\end{array}\right\} \begin{array}{r}\text { It is a boiled } \\ \text { tube absolutely } \\ \text { free from air. }\end{array}$
At the top .... at
11 A.M. $32 \cdot 280$
3 P.M. 30.518
Capacity of instrument $\frac{1}{2} \mathrm{~T}$.

11. On these results I beg leave to offer a few remarks.

The temperature of surfaces of rock exposed in subterramean situations is subject to several modifying causes.

I. The real interior temperature of the mass;

2. The local influence of external heating agents, which are, respiration of workmen, lights, explosions, and friction;

3. 'The variable influence of the air which is made to circulate through the passages of the works.

12. It is evident that the most satisfactory experiments are those in which the local and variable influences are the least possible, or else the most easily ascertainable: they cannot be wholly annihilated. In the present instance the small extent of the underground workings is very favourable; they are, in fact, only just commenced; no horses are vet let down into the pit; the extrication of gas from the fresh coal is so abundant as to compel the use of the Davy-lamp, and to require a very powerful ventilation. It is a circumstance too important to be overlooked, that the total influence of the external agents on temperature is the resultant of the heating and cooling agency of the men, lights, currents of tresh air, 8c. If this total influence, in any part of the mine, be to augment the temperature of the surfaces, the interior parts will be found colder than the surface, and the contrary.

Now in the present instance, it was found that the resultant of the external influences on the surface of the coal was powerfully refrigerating; for in those parts which were continually and had been long exposed to them, the surface temperature was either the same or a few degrees above that of the air; in the parts which had been less exposed, this temperature was higher: when fresh surfaces were exposed it was highest of all, being $9^{\circ} 6^{\prime}$ above that of the air current. A's the workiners proceed this great difference will probably diminish, and then it may be not possible so clearly to prove 
the important truth, that the hottest part is that furthest removed from external modifying causes.

13. The salt water springing up in the floor of the coal, on the dip side, is a favourable circumstance. Its temperature, like that of the fresh rock, is highest when first tried: by exposure to the external agent it is cooled nearly a degree in three hours, from a temperature which was already nearly $2^{\circ}$ too low.

14. The gas, which is constantly bubbling out from its cellular reservoirs, brings more completely, perhaps, than anything else, the real temperature of the interior. It no doubt supplies warmth to the surface of the coal, and was found hotter than the water through which it rose by no less than a degree.

15. Mr. Whitley's experiment is surely liable to no objection but one, viz. that the pouring of water at $56^{\circ}$ into so bad a conductor as coal, was likely to give a result rather below the truth.

16. I have said nothing of local chemical action, since in this situation no indications of oxides or salts of iron, or other products, depending on decomposition of pyrites, or other probable sources, have as yet manifested themselves. Besides this, all the deep coal-works of this country, as I learn from $\mathrm{Mr}$. Buddle, agree in proving the augmentation of temperature to be a general fact, independent of the pure or pyritous quality of the coal, and of the development of inflammable gas.

17. The total depth of the floor of the coal is 1584 feet; the pit top is 87 feet above ordinary high water; its depth below the level of the sea, 1497 feet. If the depth of the invariable plane be taken at 100 feet, and the mean temperature of the place $47^{\circ} \cdot 6$, we have $72^{\circ} \cdot 6-47^{\circ} \cdot 6=25^{\circ} \cdot 0$ augmentation of temperature in 1484 feet $=1^{\circ}$ for 59.36 feet, or in round numbers $1^{\circ}$ Fahr. for 20 yards English.

Newcastle, Nov. 18, 1834.

LXV. Proceedings of Learned Societies.

ROYAL SOCIETY.

[Continued from vol. iv. p. 441.]

1834. A PAPER was read, entitled, "Of the Functions of May 15.-A some parts of the Brain; and of the relations between the Brain and Nerves of Motion and Sensation." By Sir Charles Bell, K.H., F.R.S.

The author commences his paper by an enumeration of some of the sources of difficulty and of error which have impeded the progress of $3 \mathrm{M} 2$ 